\title{
A comparative summary of expression systems for the recombinant production of galactose oxidase
}

\author{
Oliver Spadiut ${ }^{1,3}$, Lisbeth Olsson ${ }^{2,4}$, Harry Brumer $1 \mathrm{II}^{1,3^{*}}$
}

\begin{abstract}
Background: The microbes Escherichia coli and Pichia pastoris are convenient prokaryotic and eukaryotic hosts, respectively, for the recombinant production of proteins at laboratory scales. A comparative study was performed to evaluate a range of constructs and process parameters for the heterologous intra- and extracellular expression of genes encoding the industrially relevant enzyme galactose 6-oxidase (EC 1.1.3.9) from the fungus Fusarium graminearum. In particular, the wild-type galox gene from F. graminearum, an optimized variant for $E$. coli and a codon-optimized gene for $P$. pastoris were expressed without the native pro-sequence, but with a His-tag either at the $\mathrm{N}$ - or the C-terminus of the enzyme.

Results: The intracellular expression of a codon-optimized gene with an N-terminal His $10^{-t a g}$ in E. coli, using the pET16 $\mathrm{b}^{+}$vector and BL21DE3 cells, resulted in a volumetric productivity of $180 \mathrm{U} \cdot \mathrm{L}^{-1} \cdot \mathrm{h}^{-1}$. The intracellular expression of the wild-type gene from F. graminearum, using the pPIC3.5 vector and the P. pastoris strain GS115, was poor, resulting in a volumetric productivity of $120 \mathrm{U} \cdot \mathrm{L}^{-1} \cdot \mathrm{h}^{-1}$. Furthermore, this system did not tolerate an N-terminal His ${ }_{10^{-}}$ tag, thus rendering isolation of the enzyme from the complicated mixture difficult. The highest volumetric productivity $\left(610 \mathrm{U} \cdot \mathrm{L}^{-1} \cdot \mathrm{h}^{-1}\right)$ was achieved when the wild-type gene from F. graminearum was expressed extracellularly in the P. pastoris strain SMD1168H using the pPICZ $\alpha$-system. A C-terminal His 6 -tag did not significantly affect the production of the enzyme, thus enabling simple purification by immobilized metal ion affinity chromatography. Notably, codon-optimisation of the galox gene for expression in $P$. pastoris did not result in a higher product yield ( $\mathrm{g}$ protein. $\mathrm{L}^{-1}$ culture). Effective activation of the enzyme to generate the active-site radical copper complex could be equally well achieved by addition of $\mathrm{CuSO}_{4}$ directly in the culture medium or post-harvest.

Conclusions: The results indicate that intracellular production in E. coli and extracellular production in P. pastoris comprise a complementary pair of systems for the production of GalOx. The prokaryotic host is favored for highthroughput screening, for example in the development of improved enzymes, while the yeast system is ideal for production scale-up for enzyme applications.
\end{abstract}

\section{Background}

Galactose 6-oxidase (GalOx; D-galactose:oxygen 6-oxidoreductase; EC 1.1.3.9) is a monomeric, free radical copper oxidase that oxidizes a range of primary alcohols to aldehydes, especially the C6 hydroxyl group of galactose [1]. GalOx is naturally secreted by a number of filamentous fungi, most prominently Fusarium spp. [2,3],

\footnotetext{
* Correspondence: harry@biotech.kth.se

'Division of Glycoscience, School of Biotechnology, Royal Institute of

Technology (KTH), SE-106 91 Stockholm, Sweden

Full list of author information is available at the end of the article
}

with the GalOx from $F$. graminearum being perhaps the most well-studied representative [4-7]. Due to a particularly high selectivity for galactose and galactose-containing oligo- and polysaccharides, GalOx has been harnessed for a diversity of biotechnological applications. GalOx has been successfully applied in biosensors to measure the lactose concentration in dairy products $[8,9]$ and the presence of glycoproteins in biomaterials [10]. It has also been used in chemical synthesis and various diagnostic applications in medicine [11,12]. Oxidation of galactosylated polysaccharides, in particular
Ciomed Central

C 2010 Spadiut et al; licensee BioMed Central Ltd. This is an Open Access article distributed under the terms of the Creative Commons Attribution License (http://creativecommons.org/licenses/by/2.0), which permits unrestricted use, distribution, and reproduction in any medium, provided the original work is properly cited. 
galactomannans and xyloglucans from plant seeds, has been employed for multivalent functionalization of these biopolymers [13-15]. The resulting aldehyde derivatives can be used directly e.g. as strength additives in the paper industry $[14,16]$, oxidized to carboxylic acids [16] or further derivatized to install chemical functional groups [13].

The catalytic two-electron oxidation catalyzed by GalOx follows a ping-pong bi-bi mechanism, mediated by a redox-active copper ion coordinated to a thioetherbridged tyrosylcysteine (Tyr-Cys) residue formed by post-translational oxidation [5,7]. In the fully oxidized (active) form of GalOx, the Tyr-Cys residue is in the radical form and the copper atom is in the +2 oxidation state $\left(\mathrm{Cu}^{2+} / \mathrm{Tyr}-\mathrm{Cys}\right.$ form $)[3,5]$. Oxidation of primary alcohols to the corresponding aldehydes reduces the cofactor to the $\mathrm{Cu}^{1+} / \mathrm{Tyr}$-Cys (non-radical) species, which is subsequently re-oxidized by $\mathrm{O}_{2}$ to the $\mathrm{Cu}^{2}$ ${ }^{+} /$Tyr-Cys' form, yielding $\mathrm{H}_{2} \mathrm{O}_{2}$ as a product (Figure 1).

For fundamental studies and applications, the GalOx from $F$. graminearum has been recombinantly produced in a range of microbial hosts, including Escherichia coli $[17,18]$, Pichia pastoris $[5,14,19]$ and Aspergillus nidulans [20]. The factors dictating the choice of expression host are manifold, including growth rate, complexity of growth medium and handling, ease of transformation, potential for post-translational protein modification, ease of harvest, extent of endogenous contaminants, overall productivity, etc. In this context, Escherichia coli and Pichia pastoris have become the pre-eminent proand eukaryotic microbial hosts, respectively, for routine laboratory use. Despite individual reports of the successful use of $E$. coli and P. pastoris for GalOx production, a direct, practical comparison has not been performed thus far. In the present study, we have therefore explored a variety of codon-optimized and affinitytagged variants of the galox gene from F. graminearum for the recombinant production of the enzyme in these hosts. This study highlights the advantages and limitations of particular gene construct-host systems, with respect to their suitability for high-throughput screening and up-scaling for enzyme applications.

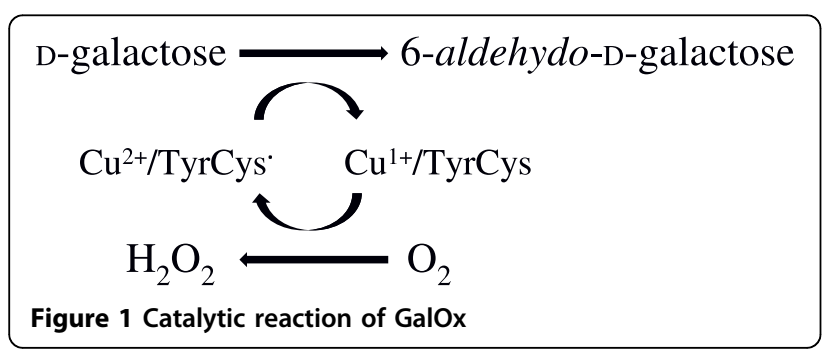

\section{Materials and methods}

\section{Genes and vectors}

The nucleotide and amino acid sequences of all constructs used in the present study, omitting both the propeptide sequence and the native signal peptide, are available in Additional File 1 (Figures S1-S12).

All cloning steps were performed using standard molecular biology techniques. A list of the oligonucleotide primers used is given in Table S1 (Additional File 1). Correct insertion of the GalOx-encoding genes and the absence of mutations were checked by DNA sequencing using the primers T7fwd and T7rev for the E. coli constructs or 5'AOX1 and 3'AOX1 for the P. pastoris constructs, respectively (Table S1, Additional File 1). Nucleotides, buffers and enzymes were purchased from Fermentas (Stockholm, Sweden).

\section{Expression in E. coli}

The wild-type galox gene from Fusarium graminearum (wtgalox) and a variant optimized for the expression in E. coli (M1galox) were generously provided by Prof. Nicholas Turner (University of Manchester, UK). The M1 variant differs from the wild-type in 5 amino acid substitutions (S10P, M70V, G195E, V494A, N535D), which have shown beneficial effects on the expression level and the stability of GalOx in E. coli $[17,18]$. The two genes, coding only for the mature GalOx protein, were cloned into a pET16b ${ }^{+}$vector (Novagen, Darmstadt, Germany) with an N-terminal $\mathrm{His}_{10}$-tag and an IPTG-inducible T7 promoter for the intracellular expression in E. coli [18].

\section{Expression in P. pastoris}

To test the intracellular expression in P. pastoris, both galox genes were cloned into the pPIC3.5 vector (Invitrogen, CA, USA) using the restriction sites AvrII and NotI. For extracellular expression the genes were cloned into the pPICZ $\alpha-C$ vector (Invitrogen), providing the $\alpha$ factor signal sequence for secretion, using the restriction sites $N o t \mathrm{I}$ and $\mathrm{XbaI}$. For all these constructs, integration of the galox gene occurred at the AOX1 locus in the genome of $P$. pastoris. To check the effect of a His-tag on the expression level and the activity of GalOx, different constructs were prepared either with or without an $\mathrm{N}$-terminal $\mathrm{His}_{10}$-tag following the $\alpha$-factor secretion signal peptide. A galox gene codon-optimized for the expression in the yeast $P$. pastoris (Additional File 1, Figure S13), was synthesized (GenScript, NJ, USA) and cloned into the pPICZ $\alpha-C$ vector with or without a Cterminal $\mathrm{His}_{6}$-tag using the restriction sites Not $\mathrm{I}$ and $X b a \mathrm{I}$. The optimization parameters were determined according to the OptimumGene ${ }^{\mathrm{Tu}}$ algorithm (GenScript, NJ, USA) taking into account the e.g. codon usage bias, GC content, mRNA secondary structures and RNA instability motifs. 


\section{Media and strains}

E. coli TOP10 cells were used for maintenance and propagation of all plasmids. For expression trials in bacteria, the E.coli strain BL21DE3 was used. Intracellular expression in P. pastoris was performed in the strain GS115 and for extracellular expression the protease-deficient P. pastoris strain SMD1168H was used. Names of all recombinant strains are given in Table 1. A 3-letter code following the standard organism binomial nomenclature describes the features of the constructs: F, wildtype galox gene from F. graminearum; E, galox gene optimized for the expression in E. coli; P, galox gene optimized for the expression in P. pastoris; $\mathrm{N}, \mathrm{N}$-terminal $\mathrm{His}_{10}$-tag; $\mathrm{x}$, no His-tag; C, C-terminal $\mathrm{His}_{6}$-tag; I, intracellular expression; E, extracellular expression.

For propagation of the different constructs, E. coli cells were cultivated in LB-medium (yeast extract $5 \mathrm{~g} \cdot \mathrm{L}^{-}$ ${ }^{1}$; tryptone $10 \mathrm{~g} \cdot \mathrm{L}^{-1} ; \mathrm{NaCl} 10 \mathrm{~g} \cdot \mathrm{L}^{-1} ; \mathrm{pH}$ 7.5) or Low Salt LB-medium (yeast extract $5 \mathrm{~g} \cdot \mathrm{L}^{-1}$; tryptone $10 \mathrm{~g} \cdot \mathrm{L}^{-1}$; $\mathrm{NaCl} 5 \mathrm{~g} \cdot \mathrm{L}^{-1} ; \mathrm{pH}$ 7.5) under appropriate selective conditions (ampicillin or zeocin was added to a final concentration of $0.1 \mathrm{~g} \cdot \mathrm{L}^{-1}$ or $0.025 \mathrm{~g} \cdot \mathrm{L}^{-1}$, respectively) according to the manufacturer's protocol (Invitrogen). Expression studies in E. coli were performed in $\mathrm{TB}_{\mathrm{amp}}$-medium (yeast extract $24 \mathrm{~g} \cdot \mathrm{L}^{-1}$; peptone from casein $12 \mathrm{~g} \cdot \mathrm{L}^{-1}$; glycerol $4 \mathrm{~mL} \cdot \mathrm{L}^{-1} ; \mathrm{KH}_{2} \mathrm{PO}_{4}$-buffer $1 \mathrm{M}$, pH 7.5; ampicillin $\left.0.1 \mathrm{~g} \cdot \mathrm{L}^{-1}\right)$.

P. pastoris clones were propagated in YPD medium (yeast extract $10 \mathrm{~g} \cdot \mathrm{L}^{-1}$; peptone $20 \mathrm{~g} \cdot \mathrm{L}^{-1}$; dextrose $10 \mathrm{~g} \cdot \mathrm{L}-$ $\left.{ }^{1}\right)$ under appropriate selective conditions. After transformation of the P. pastoris strain GS115 with linearized pPIC3.5/galox constructs, cells were spread on $\mathrm{RDB}_{\mathrm{amp}}$ (Regeneration Dextrose Base) plates and incubated at $30^{\circ} \mathrm{C}$ for $48 \mathrm{~h}$. SMD1168H cells were transformed with linearized pPICZ $\alpha-\mathrm{C} /$ galox constructs and grown on
YPDS $_{\text {zeocin }}$ plates at $30^{\circ} \mathrm{C}$ for $48 \mathrm{~h}$. Expression experiments were performed using Buffered Glycerol-Complex Medium (BMGY) and Buffered Methanol-Complex Medium (BMMY). All media were prepared according to the manufacturer's protocol (Invitrogen).

\section{Screening for $\mathrm{His}^{+} \mathrm{Mut}^{+}$or $\mathrm{His}^{+} \mathrm{Mut}^{\mathrm{S}}$ variants in GS115}

Correctly sequenced pPIC3.5/galox constructs were linearized with SacI and transformed into the P. pastoris strain GS115, resulting in $\mathrm{His}^{+} \mathrm{Mut}^{+}$transformants. To guarantee the correct insertion in the genomic DNA, 10 colonies of each transformation were tested for phenotype and growth on Minimal Methanol (MM) and Minimal Dextrose (MD) plates according to the manufacturer's protocol (Invitrogen).

\section{Colony screening for highly-expressing $P$. pastoris transformants}

To test the expression level in $P$. pastoris and to find a highly-expressing clone, 5 colonies of each transformation were picked and small-scale expression trials were performed. Typically (in ca. 10 independent transformations), best levels of activity were observed in two of five clones, and very high producing outliers were not observed. Transformants were precultured in 25 $\mathrm{mL}$ BMGY at $30^{\circ} \mathrm{C}$ and $220 \mathrm{rpm}$ overnight. The following day, an appropriate amount of preculture was sampled, cells were spun down and diluted in $10 \mathrm{~mL}$ $\mathrm{BMMY}$ to a final $\mathrm{OD}_{600}$ of 1.0. Cultures were grown in $50 \mathrm{~mL}$ Falcon tubes at $25^{\circ} \mathrm{C}$ and $220 \mathrm{rpm}$ for $120 \mathrm{~h}$ and methanol $(\mathrm{MeOH})$ was reconstituted to a final concentration of $0.5 \%$ every day. Samples were taken periodically and analyzed for protein content and enzymatic activity and aliquots were loaded onto SDSPAGE gels.

Table 1 Expression hosts, galox genes and vectors used in this study

\begin{tabular}{|c|c|c|c|c|c|}
\hline Strain name & Host organism & Vector & galox Gene construct & Polyhistidine tag & Localization \\
\hline$\overline{\text { E. coli } \mathrm{FNI}}$ & E. coli BL21DE3 ${ }^{\mathrm{a}}$ & pET16b ${ }^{+}$ & Fusarium wild-type & $\mathrm{N}$-terminal $\mathrm{His}_{10}$ & intracellular \\
\hline E. coli ENI & & & E. coli-optimized & $\mathrm{N}$-terminal $\mathrm{His}_{10}$ & \\
\hline P. pastoris Fxl & P. pastoris GS115 & pPIC3.5 & Fusarium wild-type & None & intracellular \\
\hline P. pastoris Exl & & & E. coli-optimized & None & \\
\hline P. pastoris $\mathrm{FNI}$ & & & Fusarium wild-type & $\mathrm{N}$-terminal $\mathrm{His}_{10}$ & \\
\hline P. pastoris ENI & & & E. coli-optimized & $\mathrm{N}$-terminal $\mathrm{His}_{10}$ & \\
\hline P. pastoris FxE & P. pastoris SMD1168H & $\mathrm{pPICZ} \alpha-\mathrm{C}$ & Fusarium wild-type & None & extracellular \\
\hline P. pastoris EXE & & & E. coli-optimized & None & \\
\hline P. pastoris FNE & & & Fusarium wild-type & $\mathrm{N}$-terminal $\mathrm{His}_{10}$ & \\
\hline P. pastoris ENE & & & E. coli-optimized & $\mathrm{N}$-terminal $\mathrm{His}_{10}$ & \\
\hline P. pastoris PxE & & & Pichia-optimized & None & \\
\hline P. pastoris $\mathrm{PCE}$ & & & Pichia-optimized & C-terminal $\mathrm{His}_{6}$ & \\
\hline
\end{tabular}

a. Genotype: $\mathrm{F}^{-}$ompT gal dcm lon $\mathrm{hsdS}_{B}\left(\mathrm{r}_{\mathrm{B}}{ }^{-} \mathrm{m}_{\mathrm{B}}{ }^{-}\right) \lambda$ (DE3 [lacl lacUV5-T7 gene 1 ind1 sam7 nin5]) [33]

b. Genotype described in ref. [34,35]

c. Genotype described in ref. [35] 


\section{Shake-flask cultivation of GalOx in E.coli BL21DE3}

Cultures (1 liter) of E. coli BL21DE3 transformants were grown in $\mathrm{TB}_{\mathrm{amp}}$ medium in baffled flasks at $37^{\circ} \mathrm{C}$ and $220 \mathrm{rpm}$. Protein expression was induced at an $\mathrm{OD}_{600}$ of $\sim 0.5$ by adding IPTG to a final concentration of 0.5 $\mathrm{mM}$. After incubation at $25^{\circ} \mathrm{C}$ for further $20 \mathrm{~h}$, approximately $15 \mathrm{~g}$ of wet biomass per liter were harvested by centrifugation at $10,000 \times \mathrm{g}$ for $15 \mathrm{~min}$ and $4^{\circ} \mathrm{C}$, and resuspended in Buffer A $\left(\mathrm{NaH}_{2} \mathrm{PO}_{4} 50 \mathrm{mM} ; \mathrm{NaCl} 500\right.$ $\mathrm{mM}$; imidazole $20 \mathrm{mM}$; $\mathrm{pH}$ 7.5) containing the protease inhibitor PMSF $(0.1 \% \mathrm{w} / \mathrm{v})$. After disruption in a French Press (1200 psi) the crude cell extract was separated from cell debris by centrifugation $\left(70,400 \times \mathrm{g}, 4^{\circ} \mathrm{C}\right)$ and used for protein purification by immobilized metal affinity chromatography (IMAC) with a $10 \mathrm{~mL} \mathrm{Ni}$-charged Sepharose 6 Fast Flow Resin (GE Healthcare; Uppsala, Sweden). Before the sample was loaded, the column was equilibrated with 10 column volumes $(\mathrm{CV})$ of buffer $\mathrm{A}$. After the protein sample was applied to the column, it was washed with $3 \mathrm{CV}$ of the same buffer, before proteins were eluted with a linear gradient (0-1 $\mathrm{M}$ imidazole) of $5 \mathrm{CV}$ Buffer B $\left(\mathrm{NaH}_{2} \mathrm{PO}_{4} 50 \mathrm{mM} ; \mathrm{NaCl} 500\right.$ $\mathrm{mM}$; imidazole $1 \mathrm{M} ; \mathrm{pH} 7.5)$. Active fractions were combined and imidazole was removed by ultrafiltration using an Amicon Ultra Centrifugal Filter Device (Millipore; Billerica, MA, USA) with a $10-\mathrm{kDa}$ cut-off membrane. The concentrated enzymes were washed 3 times with $10 \mathrm{~mL}$ of $\mathrm{NaH}_{2} \mathrm{PO}_{4}$-buffer $(100 \mathrm{mM}, \mathrm{pH} 7.5)$ and finally diluted in the same buffer to a total protein concentration of 2-3 $\mathrm{mg} \cdot \mathrm{mL}^{-1}$.

\section{Intracellular and extracellular large scale expression of GalOx in $P$. pastoris}

Highly-expressing $P$. pastoris transformants were precultured in $250 \mathrm{~mL}$ BMGY in $2 \mathrm{~L}$ baffled flasks at $30^{\circ} \mathrm{C}$ overnight. The next day, $\mathrm{OD}_{600}$ was measured, an appropriate amount of culture was sampled, cells were spun down and diluted in 1 liter BMMY to an initial $\mathrm{OD}_{600}$ of 1.0. Cultures were grown in special $2.5 \mathrm{~L}$ baffled flasks (Tunair; Sigma-Aldrich; Stockholm, Sweden) at $25^{\circ} \mathrm{C}$ and $220 \mathrm{rpm}$ up to $216 \mathrm{~h}$. To optimize the expression of active GalOx, different constructs with either a N-terminal, a C-terminal or no His-tag and different temperatures $\left(25^{\circ} \mathrm{C}\right.$ and $\left.30^{\circ} \mathrm{C}\right)$ during cultivation were tested. In addition, the expression of correctly folded enzyme was tested in the presence of copper (II) ions $\left(\right.$ as $\mathrm{CuSO}_{4}$ ), which is required for the activation of GalOx $[5,19,21]$, at a concentration of 0.5 or $1.0 \mathrm{mM}$ in the medium.

To obtain the intracellularly expressed GalOx, P. pastoris cells were were harvested by centrifugation $\left(4,000 \times \mathrm{g}, 4^{\circ} \mathrm{C}, 15 \mathrm{~min}\right)$ and resuspended in sodium phosphate buffer $(100 \mathrm{mM}, \mathrm{pH} 7.5)$ containing the complete-mini EDTA-free protease inhibitor (1 tablet per $10 \mathrm{~mL}$ buffer; Roche; Basel, CH). P. pastoris cells were disrupted in a French Press (1200 psi) and cell debris was separated by subsequent centrifugation $\left(70,400 \times \mathrm{g}, 4^{\circ} \mathrm{C}, 30 \mathrm{~min}\right)$.

\section{Analysis of expression- and growth-parameters}

Samples were taken in appropriate time intervals during cultivations and analyzed for optical density at $600 \mathrm{~nm}$ $\left(\mathrm{OD}_{600}\right)$, dry cell weight $(\mathrm{DCW})$ and concentration of expressed protein and enzymatic activity. To determine the DCW, $1 \mathrm{~mL}$ samples were taken, biomass was harvested in a previously dried and pre-weighed tube by centrifugation (4000 rpm, $5 \mathrm{~min}$ ), supernatants were discarded, cells were washed twice with ultrapure $\mathrm{H}_{2} \mathrm{O}$ and then dried at $65^{\circ} \mathrm{C}$ to a constant weight. To evaluate the process conditions, the volumetric productivity (enzyme activity units per liter culture per hour of cultivation, $\mathrm{U}$. $\mathrm{L}^{-1} \cdot \mathrm{h}^{-1}$ ) and the product yield (expressed as the mass of protein produced per mass of DCW, $g \cdot g^{-1}$ ) were determined.

\section{Enzyme activity assay}

GalOx activity was measured with the standard chromogenic ABTS [2,2'-azinobis(3-ethylbenzthiazolinesulfonic acid)] assay [20]. A sample of diluted enzyme $(10 \mu \mathrm{L})$ was added to $990 \mu \mathrm{L}$ of assay buffer containing horseradish peroxidase (142 U), ABTS $(14.7 \mathrm{mg})$, $\mathrm{NaH}_{2} \mathrm{PO}_{4}$-buffer (100 mM, pH 7.5) and D-galactose $(300 \mathrm{mM})$. The absorbance change at $420 \mathrm{~nm}\left(\varepsilon_{420}=\right.$ $42.3 \mathrm{mM}^{-1} \mathrm{~cm}^{-1}$ ) was recorded at $30^{\circ} \mathrm{C}$ for $180 \mathrm{~s}$. One Unit of GalOx activity was defined as the amount of enzyme necessary for the oxidation of $2 \mu \mathrm{mol}$ of ABTS per min, corresponding to the consumption of $1 \mu \mathrm{mol}$ of $\mathrm{O}_{2}$ per min. Protein concentrations were determined at $595 \mathrm{~nm}$ by the Bradford assay [22] using the BioRad Protein Assay Kit with BSA as standard.

\section{Posttranslational processing of GalOx}

The native GalOx enzyme is expressed as a precursor peptide with an additional 17-amino acid pro-sequence, lacking the thioether bond between Tyr272 and Cys228. In this study, GalOx was heterologously expressed in different hosts without the pro-sequence at the N-terminus. To find the optimal conditions for post-translational activation, different amounts of $\mathrm{CuSO}_{4}$ were added either to the concentrated enzyme preparations or directly into the cultivation media. After incubation, excess copper was removed by gel filtration using PD10 desalting columns (GE Healthcare), and enzymes were tested for catalytic activity and protein content and analyzed on SDS-PAGE gels. 


\section{Activation studies}

To test if the stored enzyme preparations could be further activated by the additional incubation with an oxidizing agent $[5,14,17,23,24]$, various experiments with $\mathrm{K}_{3} \mathrm{Fe}(\mathrm{CN})_{6}$ and $\mathrm{CuSO}_{4}$ were performed. Aliquots of GalOx were incubated with either $5 \mathrm{mM}, 50 \mathrm{mM}$ and $100 \mathrm{mM} \mathrm{K}_{3} \mathrm{Fe}(\mathrm{CN})_{6}$ or with additional $0.5 \mathrm{mM} \mathrm{CuSO}_{4}$ on ice for either $10 \mathrm{~min}, 1$ hour or overnight. After removal of the excessive oxidizing agent by gel filtration using PD10 desalting columns (GE Healthcare), catalytic activity with D-galactose $(300 \mathrm{mM})$ and the protein content were measured.

\section{Electrophoresis}

To check the purity of the enzyme preparations and the correct formation of the radical Tyr-Cys cofactor [5], SDS-PAGE analysis was done. The heterologously expressed GalOx in this study can run as 2 distinct bands on an SDS-PAGE gel: at $65.5 \mathrm{kDa}$ (mature GalOx containing the thioether bond) and at $68.6 \mathrm{kDa}$ (mature GalOx lacking the thioether bond). SDS-PAGE was performed using precast $10 \%$ Bis-Tris gels (Invitrogen) and 1x MOPS-buffer (MOPS $10.46 \mathrm{~g} \cdot \mathrm{L}^{-1}$; EDTA $0.3 \mathrm{~g} \cdot \mathrm{L}^{-1}$; TrisBase $6.06 \mathrm{~g} \cdot \mathrm{L}^{-1}$; SDS $1.0 \mathrm{~g} \cdot \mathrm{L}^{-1}$; pH 7.7). Gels were run in the Novex MiniCell (Invitrogen) at $150 \mathrm{~V}$ for about $2 \mathrm{~h}$. The protein mass standard used was the SeeBlue Plus 2 prestained standard (Invitrogen). Gels were stained with Coomassie blue.

\section{Western blotting}

To perform Western blotting analysis, an SDS-PAGE gel was run with $10 \mu \mathrm{L}$-aliquots of a GalOx expressed with a C-terminal $\mathrm{His}_{6}$-tag $\left(2 \mathrm{mg} \cdot \mathrm{mL}^{-1}\right.$; pure and 1:10 dilution). Proteins were transferred to a nitrocellulose membrane (Scheichler \& Schuell Protran BA83 $0.2 \mu \mathrm{M}$ ) using Towbin buffer [25] and a Trans-Blot apparatus (Biorad; Sundbyberg, Sweden). The transfer was carried out at $40 \mathrm{~V}$ overnight under gentle stirring at $4^{\circ} \mathrm{C}$. The membrane was blocked in 1xTris-buffered saline with Tween 20 (TBST; $100 \mathrm{mM}$ Tris- $\mathrm{HCl}, 150 \mathrm{mM} \mathrm{NaCl}$, $\mathrm{pH} 7.5,0,1 \%$ Tween 20) supplemented with 5\% BSA at room temperature for 2 hours and then incubated with a 1:5000 dilution (v/v) of an anti $\mathrm{His}_{6}$ antibody conjugated to horse radish peroxidase (Pierce, Biocompare; CA, USA) at room temperature with gentle rocking for another 2 hours. The membrane was extensively washed in TBST and then revealed using the ECL kit (Amersham; Uppsala, Sweden). The images were acquired with a GelDoc camera (Biorad) using the chemiluminescence filter.

\section{Storage stability of GalOx preparations from $P$. pastoris}

To find the best conditions to store the large amounts of GalOx produced in P. pastoris for an extended period of time, different conditions were tested. Enzyme solution was aliquoted in $500 \mathrm{~L}$ portions and either stored at $4{ }^{\circ} \mathrm{C}$, snap-frozen in liquid $\mathrm{N}_{2}$ and stored at $-80^{\circ} \mathrm{C}$ or lyophilized and stored at $-20^{\circ} \mathrm{C}$. After different time intervals samples were thawed on ice and catalytic activity and protein content were measured. Storage at $4^{\circ} \mathrm{C}$ was tested for 4 weeks, and samples were analyzed every day. Lyophilized samples were resuspended in the same amount of buffer $(500 \mu \mathrm{L})$ and the activity at a substrate concentration of $300 \mathrm{mM}$ D-galactose were determined and the protein content were compared to the values before lyophilisation.

\section{Results and Discussion}

In this study, different strategies for the recombinant production of GalOx were compared to systematically explore the advantages and potential drawbacks of each system. An overview of the strain names, the GalOx gene constructs, expression vectors, and host organisms is given in Table 1.

F. graminearum GalOx is naturally produced as a prepro-enzyme containing a 17 amino acid $\mathrm{N}$-terminal sequence that is cleaved to yield the "immature" form of the enzyme. A previous study suggested that the prosequence was required as an intramolecular chaperone for copper binding and cofactor formation [24]. In contrast, however, fully active GalOx has been successfully produced in a number of cases by aerobic addition of copper (II) to versions of GalOx lacking this prosequence $[5,19,21]$. Additionally, Pichia pastoris is not able to efficiently process the native signal sequence [26]. Thus, all gene constructs in this study were designed to omit both the pro-peptide sequence and the native signal peptide (see Additional File 1, Figure S1S12).

\section{Intracellular expression of GalOx in E. coli}

To quantify the expression of active GalOx from $F$. graminearum in the prokaryotic host E. coli, 2 genes, the wild-type galox gene (wtgalox) and the optimized variant M1 (M1galox), were cloned into a pET16b ${ }^{+}$ vector and transformed into the $E$. coli strain BL21DE3 to give $E$. coli FNI and E. coli ENI, respectively (Table $1)$. The optimized gene M1 differs in 5 amino acid substitutions (see Additional File 1), which have been reported to result in a higher expression yield and increased stability of the fungal enzyme in $E$. coli $[17,18]$. In these studies, a higher expression of $\mathrm{GalOx}$ in $E$. coli was desired for high-throughput screening in the context of directed evolution studies for altering the substrate specificity of this enzyme $[17,18]$. However, a detailed analysis and explicit comparison of the expression levels of these 2 genes in $E$. coli has not been performed previously. 
Both the wild-type and M1-variant genes used in this study encoded the mature GalOx protein, in which the native signal sequence and the pro-sequence were replaced with an $\mathrm{N}$-terminal $\mathrm{His}_{10}$-tag. Following successful expression of both constructs in E. coli and cell disruption in a French Press, GalOx was purified from the crude extracts using IMAC. The resulting purification factor was 93.8 for the wild-type enzyme and 109.0 for the optimized variant M1. The expression level of the optimized gene was 10 -fold higher than that of wtgalox $\left(4.1 \mathrm{mg} \cdot \mathrm{mL}^{-1}\right.$ and $0.4 \mathrm{mg} \cdot \mathrm{mL}^{-1}$ were obtained, respectively). Likewise, the specific activity of the purified M1 product was higher by a factor of $2.4\left(24 \mathrm{U} \cdot \mathrm{mg}^{-}\right.$ ${ }^{1}$ versus $10 \mathrm{U} \cdot \mathrm{mg}^{-1}$ for wtgalox), prior to further activation with copper (II) ions.

To analyze the optimal conditions for the post-translational activation of the immature GalOx with copper (II) ions $[5,19,21]$, the purified enzyme variant GalOxM1 was incubated with different concentrations of $\mathrm{CuSO}_{4}$ at $4^{\circ} \mathrm{C}$ and stirring overnight. After incubation, excess copper was removed by gel filtration and enzymatic activity was measured. Incubation with $0.5 \mathrm{mM} \mathrm{CuSO}_{4}$ resulted in the highest activation of GalOx (Figure 2), the specific activity of purified GalOxM1 increased 7.5-fold from $24 \mathrm{U} \cdot \mathrm{mg}^{-1}$ to $180 \mathrm{U} \cdot \mathrm{mg}^{-1}$. This latter specific activity value is equivalent to a $v_{\mathrm{o}}[\mathrm{E}]_{\mathrm{t}}^{-1}$ value of $190 \mathrm{~s}^{-1}$, which was obtained at $20 \times K_{\mathrm{m}}(300 \mathrm{mM} \mathrm{Gal}$, see Materials and Methods) [18]. This value compares favorably with the $k_{\text {cat }}$ value of $156 \mathrm{~s}^{-1}$ previously determined for this enzyme variant [18]. Thus, the kinetic data indicate that the degree of enzyme activation may supercede that obtained in previous studies. To check the purity of the enzyme and the correct formation of the radical cofactor in the active site [5,24], aliquots of the purified enzyme were loaded onto an SDS-PAGE gel (Figure 3A). A band at an apparent mobility of $65 \mathrm{kDa}$, which

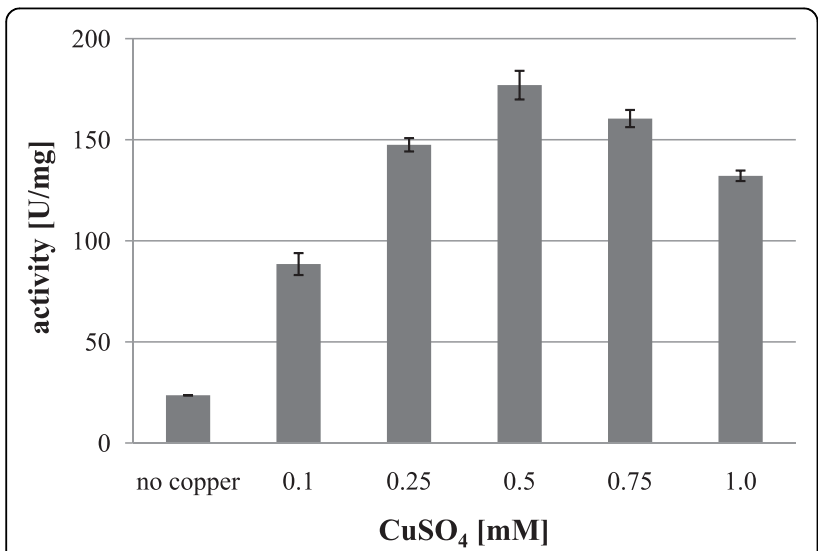

Figure 2 Analysis of the optimal concentration for the posttranslational activation with $\mathrm{CuSO}_{4}$ of $\mathrm{GalOx}$ expressed in E. coli. corresponds to the mature GalOx containing the correctly formed Tyr-Cys radical, can be seen in lanes 4-7. It has been observed previously that activation of the immature form of $\mathrm{GalOx}(68 \mathrm{kDa})$ causes a mobility shift in SDS-PAGE, which can be used as an indicator of the degree of activation [5,24].

Clearly, GalOx proteins lacking the pro-sequence can be successfully processed post-purification by the addition of $0.5 \mathrm{mM} \mathrm{CuSO}_{4}$ under aerobic conditions to yield the catalytically active, mature species. Using this strategy, after $20 \mathrm{~h}$ of expression at $25^{\circ} \mathrm{C}, 3600 \mathrm{U} \cdot \mathrm{L}^{-1}$ active GalOxM1 could be obtained, resulting in a volumetric productivity of $180 \mathrm{U} \cdot \mathrm{L}^{-1} \cdot \mathrm{h}^{-1}$ for this expression system under these conditions. This expression level of the fungal enzyme GalOx in the prokaryotic host $E$. coli thus forms a platform for directed evolution studies of this enzyme $[17,18]$, where a rapid, easily implemented expression system is advantageous.

\section{Intracellular expression of GalOx in P. pastoris}

The methylotrophic yeast Pichia pastoris has become one of the leading eukaryotic expression systems for general laboratory use due to its ease of cultivation and the availability of a range of commercially available expression vectors $[27,28]$. Indeed, strain and vector systems have been developed, which allow both intra- and extracellular protein production under the control of various promoters, the most common being the methanol-induced alcohol oxidase 1 (AOX1) promoter [29].

To examine the intracellular expression in the eukaryotic host $P$. pastoris, the wtgalox gene and the variant M1galox were cloned into the pPIC3.5 vector, with or without an $\mathrm{N}$-terminal $\mathrm{His}_{10}$-tag, and transformed into the $P$. pastoris strain GS115 to give $P$. pastoris strains FNI, ENI, FxI and ExI (Table 1). Clones selected for highest expression level of GalOx were subsequently cultivated at $1 \mathrm{~L}$-scale at $25^{\circ} \mathrm{C}$ over a period of five days to monitor enzyme production (Table 2 and Figure 3B).

The expression of the wtgalox gene from the fungus $F$. graminearum in the yeast $P$. pastoris was slightly better than the M1galox gene, which had been optimized for the expression in E. coli (Table 2). The incubation with 0.5 $\mathrm{mM} \mathrm{CuSO}_{4}$ efficiently activated the GalOx enzyme in the crude extracts and resulted in an increase of activity up to 15-fold, with lower degrees of activation observed in variants bearing a $\mathrm{N}$-terminal $\mathrm{His}_{10}$-tag. The wtgalox gene yielded the highest amount of expressed, active GalOx enzyme and a volumetric productivity of $120 \mathrm{U} \cdot \mathrm{L}^{-1} \cdot \mathrm{h}^{-1}$. Notably, the presence of an N-terminal His ${ }_{10}$-tag on both the wild-type and M1 variants severely suppressed the yield of enzyme obtained in cultivations (Table 2).

As shown in Figure 3B, bands at $65 \mathrm{kDa}$, corresponding to the mature GalOx enzyme containing the TyrCys cofactor, but also bands at $68 \mathrm{kDa}$, possibly 


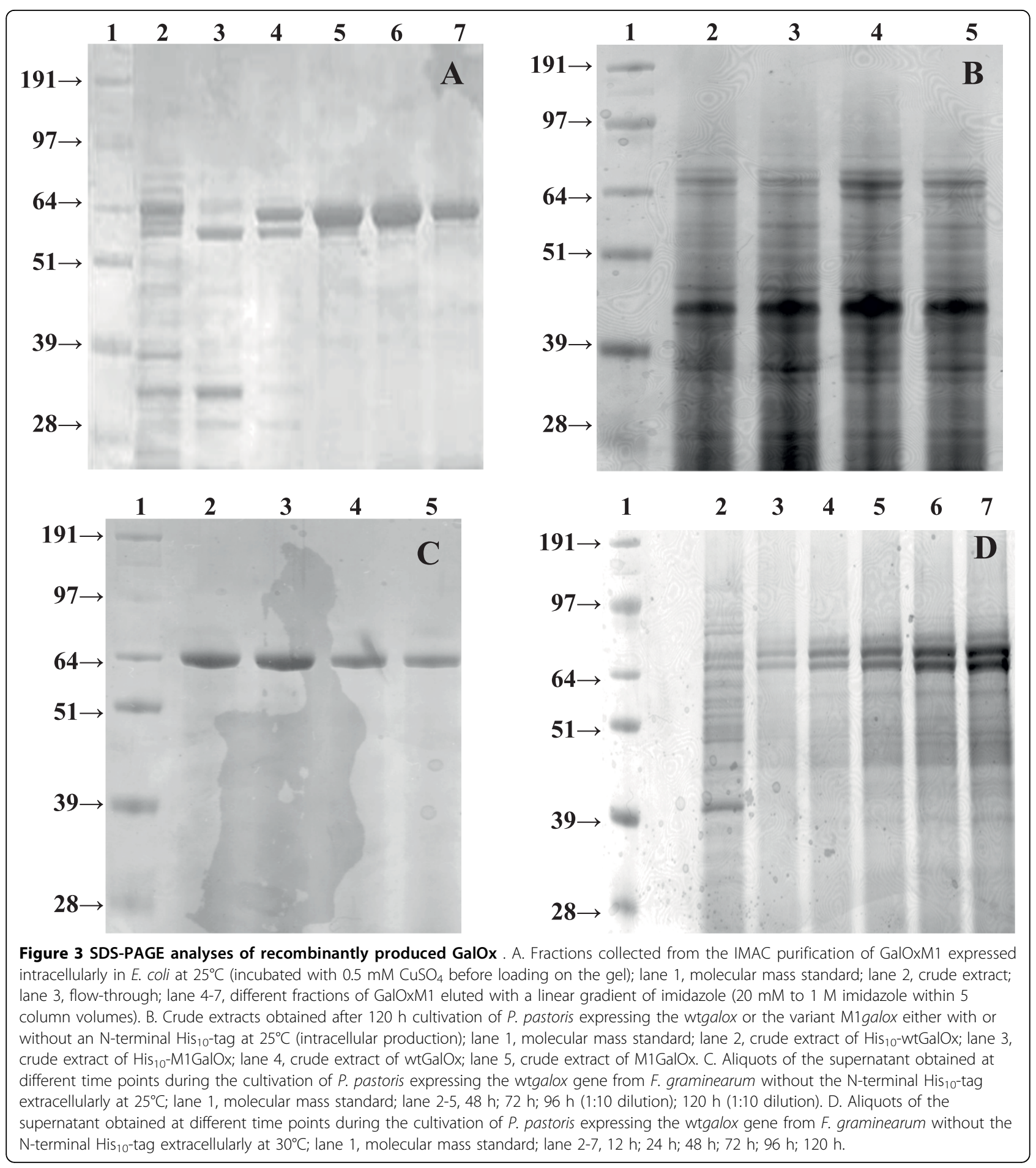

corresponding to the pre-mature GalOx lacking the radical cofactor in the active site $[5,24]$, could be detected. However, incubation with up to $2.0 \mathrm{mM}$ $\mathrm{CuSO}_{4}$ did not result in an increased amount of active GalOx, but rather in a decrease in protein content after the incubation because of protein denaturation. As a consequence of the intracellular production, many other proteins were detected in the crude extracts (Figure 3B), which could also influence the copper-activation of GalOx and further complicate subsequent purification in the absence of an affinity tag. Generally speaking, the lower volumetric productivity of the intracellular $P$. pastoris system indicates that this system is not competitive with intracellular expression in E. coli. 
Table 2 Volumetric activity of GalOx expressed intracellularly in $P$. pastoris

\begin{tabular}{lcccccc}
\hline & \multicolumn{7}{c}{ vol. activity $^{\mathbf{b}}\left[\mathbf{U} \cdot \mathbf{m L}^{-\mathbf{1}}\right]$} \\
\hline strain $^{\mathbf{a}}$ & $\mathbf{2 4} \mathbf{~ h}$ & $\mathbf{4 8} \mathbf{~ h}$ & $\mathbf{7 2} \mathbf{~ h}$ & $\mathbf{9 6} \mathbf{~}$ & $\mathbf{1 2 0} \mathbf{~}$ & $\mathbf{1 2 0} \mathbf{~}^{\mathbf{c}}$ \\
\hline P. pastoris FXI & 3.2 & 7.4 & 11.0 & 14.0 & 14.0 & 0.9 \\
P. pastoris EXI & 1.7 & 4.2 & 7.1 & 10.0 & 11.0 & 0.8 \\
P. pastoris FNI & 0.7 & 1.3 & 1.9 & 2.4 & 2.5 & 0.5 \\
P. pastoris ENI & 0.6 & 1.0 & 1.8 & 2.2 & 2.2 & 0.4 \\
\hline
\end{tabular}

a See Table 1

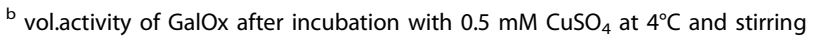
overnight; wild-type GalOx from F. graminearum and the variant $\mathrm{M} 1$ with or without an $\mathrm{N}$-terminal $\mathrm{His}_{10}$-tag were expressed intracellularly in $\mathrm{P}$. pastoris GS115 at $25^{\circ} \mathrm{C}$ for 120 hours

${ }^{c}$ vol. activity $\left[\mathrm{U} \cdot \mathrm{mL}^{-1}\right.$ ] before the incubation with $0.5 \mathrm{mM} \mathrm{CuSO}{ }_{4}$

\section{Extracellular expression of GalOx in P. pastoris}

One of the key advantages of $P$. pastoris for recombinant protein production lies in the ability of this yeast to secrete proteins to the culture medium under the agency of the Saccharomyces cerevisiae $\alpha$-factor secretion signal peptide $[27,30]$. P. pastoris in general secretes low levels of endogenous proteins, and the SMD1168H strain in particular has low detrimental protease activity, thus facilitating the recovery and downstream processing of reasonably pure crude extracts. For comparison with the E. coli and P. pastoris intracellular production systems, the expression of the wild-type, M1 (E. coli optimized) and P. pastoris codon-optimized variant of galox was examined in combination with various His affinity tag strategies (Table 1).

Effect of $\mathrm{N}$-terminal His ${ }_{10}$-tag on expression of wtgalox and M1galox

The wtgalox gene and the optimized variant M1galox were cloned into the pPICZ $\alpha-C$ vector with or without an $\mathrm{N}$-terminal $\mathrm{His}_{10}$-tag and transformed into the P. pastoris strain SMD1168H to give P. pastoris strains FNE, ENE, FxE and ExE (Table 1). After colony screening, clones with the highest expression level of $\mathrm{GalOx}$ were cultivated in shake-flask cultivations $(1 \mathrm{~L})$ at $25^{\circ} \mathrm{C}$ for $120 \mathrm{~h}$ and analyzed periodically. After determining the optimal amount of $\mathrm{CuSO}_{4}$ for activation (data not shown, similar to Figure 2), enzymatic activity was measured in the crude extracts before and after incubation with $0.5 \mathrm{mM} \mathrm{CuSO}_{4}$ and stirring overnight.

After $120 \mathrm{~h}$ of cultivation, incubation with $\mathrm{CuSO}_{4}$ increased GalOx activity up to 14 -fold (Table 3). As observed before for the intracellular expression in $P$. pastoris, the presence of the $\mathrm{N}$-terminal $\mathrm{His}_{10}$-tag in both gene variants significantly reduced enzyme production; the wtgalox gene from $F$. graminearum without the $\mathrm{N}$-terminal $\mathrm{His}_{10}$-tag resulted in the highest amount of active GalOx enzyme and a volumetric productivity of $610 \pm 30 \mathrm{U} \cdot \mathrm{L}^{-1} \cdot \mathrm{h}^{-1}$ (Table 3). As in the intracellular cases, the wtgalox gene from $F$. graminearum yielded more enzyme in P. pastoris than the M1galox gene, which had been optimized for $E$. coli expression. The resulting preparations had a specific activity of $260 \pm 14$ $\mathrm{U} \mathrm{mg}^{-1}$ (Table 4). This equates to a $v_{\mathrm{o}}[\mathrm{E}]_{\mathrm{t}}^{-1}$ value of $280 \mathrm{~s}^{-1}$, which was obtained at $300 \mathrm{mM} \mathrm{Gal}\left(3.6 \times K_{\mathrm{m}}\right.$ [4], see Materials and Methods). Assuming standard Michaelis-Menten kinetics, at this substrate concentration the $v_{\mathrm{o}}[\mathrm{E}]_{\mathrm{t}}^{-1}$ value is ca. $78 \%$ of the $k_{\mathrm{cat}}$ value. The $k_{\text {cat }}$ value for recombinant, wild-type GalOx from $F$. graminearum has been previously determined to be $503 \pm$ $16 \mathrm{~s}^{-1}$ [4], which implies that GalOx produced by strain P. pastoris FxE (Table 1) is ca. $70 \%$ active. SDS-PAGE analysis (Coomassie staining, Figure $3 \mathrm{C}$ ) of the cultivation broth at different time points indicated, however, that a single protein band at $65 \mathrm{kDa}$ was produced, corresponding to the mature $\mathrm{GalOx}$ with the correctly formed Tyr-Cys cofactor [5,24]. As GalOx constituted for the majority of the secreted proteins in these samples, a simple purification by $\left(\mathrm{NH}_{4}\right)_{2} \mathrm{SO}_{4}$ precipitation, dialysis, and ultrafiltration was performed. However, media components in the concentrated enzyme preparation led to a brown color, which hindered the analysis of the oxidation state of the enzyme by visible spectroscopy $(445 \mathrm{~nm},[5,17])$.

\section{Effect of cultivation temperature on enzyme yield}

Since the volumetric productivity was more than 3 -fold higher for the extracellular expression of the wtgalox gene (without His tag) in P. pastoris compared to the production of GalOx in E. coli, we chose this system to test different cultivation conditions. After $120 \mathrm{~h}$ of cultivation at $25^{\circ} \mathrm{C}$, the $\mathrm{OD}_{600}$, the $\mathrm{DCW}$ and the total protein content in the medium were still increasing, implying that the culture had still not reached the stationary phase yet (graphs not shown). Therefore we performed 2 cultivations in parallel, at $25^{\circ} \mathrm{C}$ and the more commonly used $30^{\circ} \mathrm{C}$ [31], for an extended time of 216 h. After $216 \mathrm{~h}$ of cultivation and activation of the enzyme with $0.5 \mathrm{mM} \mathrm{CuSO}$ overnight, $150 \mathrm{U} \cdot \mathrm{mL}^{-1}$ GalOx were obtained at $25^{\circ} \mathrm{C}$, whereas only $56 \mathrm{U} \cdot \mathrm{mL}^{-1}$ were obtained at $30^{\circ} \mathrm{C}$. The protein contents in the media were comparable for both temperatures $\left(0.57 \mathrm{mg} \cdot \mathrm{mL}^{-1}\right.$ at $25^{\circ} \mathrm{C}$ and $0.52 \mathrm{mg} \cdot \mathrm{mL}^{-1}$ at $30^{\circ} \mathrm{C}$, respectively) resulting in specific activities of $254 \mathrm{U} \cdot \mathrm{mg}^{-1}$ at $25^{\circ} \mathrm{C}$ and $108 \mathrm{U} \cdot \mathrm{mg}^{-1}$ at $30^{\circ} \mathrm{C}$, respectively. However, as shown in Figure 3D, P. pastoris secreted a more complex mixture of proteins into the medium ( $c f$. Figure $3 \mathrm{C})$. The presence of strong bands with apparent mobilities of $65 \mathrm{kDa}$ and $68 \mathrm{kDa}$ suggests that the higher temperature resulted in partly misfolded constructs, which could not be correctly activated to generate the Tyr-Cys radical co-factor by the addition of copper (II) ions under aerobic conditions. A similar negative effect of increasing the cultivation temperature on production yield of $P$. pastoris has been observed previously [26], 
Table 3 Catalytic activity and protein content of GalOx expressed extracellularly in $P$. pastoris

\begin{tabular}{|c|c|c|c|c|c|c|c|c|}
\hline \multirow[b]{2}{*}{ strain $^{a}$} & \multicolumn{8}{|c|}{ vol. activity ${ }^{\mathrm{b}}\left[\mathrm{U} \cdot \mathrm{mL}^{-1}\right]$} \\
\hline & $24 \mathrm{~h}$ & $48 \mathrm{~h}$ & $72 \mathrm{~h}$ & $96 \mathrm{~h}$ & & $120 \mathrm{~h}$ & & $120 \mathrm{~h}^{\mathrm{c}}$ \\
\hline & & & & & vol. activity $\left[\mathrm{U} \cdot \mathrm{mL}^{-1}\right]$ & protein $\left[\mathrm{mg} \cdot \mathrm{mL}^{-1}\right]$ & spec. activity $\left[\mathrm{U} \cdot \mathrm{mg}^{-1}\right]$ & \\
\hline P. pastoris FxE & 15.2 & 29.0 & 55.0 & 69.0 & 73.0 & 0.28 & 260 & 6.1 \\
\hline P. pastoris ExE & 15.0 & 27.0 & 43.0 & 60.0 & 61.0 & 0.24 & 254 & 4.3 \\
\hline P. pastoris FNE & 5.3 & 6.0 & 6.2 & 7.6 & 7.3 & 0.12 & 61 & 1.1 \\
\hline P. pastoris ENE & 3.0 & 5.6 & 5.7 & 5.9 & 6.1 & 0.10 & 61 & 1.0 \\
\hline
\end{tabular}

a See Table 1

${ }^{\mathrm{b}}$ catalytic activity and protein content after incubation with $0.5 \mathrm{mM} \mathrm{CuSO}_{4}$ at $4^{\circ} \mathrm{C}$ and stirring overnight; wild-type GalOx from $\mathrm{F}$. graminearum and the variant $\mathrm{M} 1$ with or without an $\mathrm{N}$-terminal $\mathrm{His}_{10}$-tag were expressed extracellularly in $\mathrm{P}$. pastoris $\mathrm{SMD} 1168 \mathrm{H}$ at $25^{\circ} \mathrm{C}$ for 120 hours

${ }^{c}$ vol. activity $\left[\mathrm{U} \cdot \mathrm{mL}^{-1}\right.$ ] before the incubation with $0.5 \mathrm{mM} \mathrm{CuSO}_{4}$

thus suggesting that lower-temperature production strategies are to be preferred. Interestingly, even after $216 \mathrm{~h}$ of cultivation at $25^{\circ} \mathrm{C}$, the $\mathrm{OD}_{600}$ value and the protein content in the medium were still increasing (Figure 4). However, for practical reasons, cultivation times of more than $216 \mathrm{~h} \mathrm{(9} \mathrm{d)} \mathrm{were} \mathrm{not} \mathrm{tested.}$

\section{Direct activation of GalOx in the cultivation medium}

To streamline the extracellular production of $\mathrm{GalOx}$ by $P$. pastoris, the direct activation of $\mathrm{GalOx}$ by supplementing copper (II) in the culture medium was tested. Transformants were cultivated in BMMY supplemented with $\mathrm{CuSO}_{4}$ to final concentrations of 0.5 and $1.0 \mathrm{mM}$ $\left(2 \mathrm{mM} \mathrm{Cu}^{++}\right.$is known to result in growth toxicity to $P$. pastoris [32]). P. pastoris resulted in a final $\mathrm{OD}_{600}$ between 65-70 and a final dry cell weight between 45-50 $\mathrm{mg} \cdot \mathrm{mL}^{-1}$ after 216 hours regardless of the presence of copper in the medium. The protein content in the medium was also comparable between the different cultivations; without copper in the medium a protein concentration of $0.57 \mathrm{mg} \cdot \mathrm{mL}^{-1}$ was obtained, and in the presence of 0.5 and $1.0 \mathrm{mM}$ copper $0.54 \mathrm{mg} \cdot \mathrm{mL}^{-1}$ and $0.50 \mathrm{mg} \cdot \mathrm{mL}^{-1}$ could be measured, respectively.

As desired, addition of copper (II) in the growth medium resulted in the immediate activation of GalOx (Figure 5). Subsequent incubation of the enzyme with additional $0.5 \mathrm{mM} \mathrm{CuSO}_{4}$ at $4{ }^{\circ} \mathrm{C}$ and stirring overnight did not result in further activation, implying that the presence of copper in the cultivation medium was sufficient for effective processing of GalOx. Assuming 100\% activation in all cases, the protein concentration values indicate a slightly reduced productivity with increasing concentrations of copper (II) ions in the medium, perhaps due to metal ion toxicity. The highest amount of active GalOx, and therefore the highest volumetric productivity of $610 \mathrm{U} \cdot \mathrm{L}^{-1} \cdot \mathrm{h}^{-1}$, was obtained when $P$. pastoris was cultivated without additional $\mathrm{CuSO}_{4}$ in the medium and $\mathrm{GalOx}$ was subsequently activated by $0.5 \mathrm{mM}$ $\mathrm{CuSO}_{4}$. Consequently, post-harvest activation of GalOx with copper (II) was used for further experiments.

\section{Codon-optimization of GalOx for P. pastoris and effect of}

\section{C-terminal His ${ }_{6}$-tag addition}

To test the possibility of further improving the extracellular expression of GalOx in P. pastoris, a codon-optimized variant for $P$. pastoris was obtained by gene synthesis. The sequence identity between the wtgalox gene from $F$. graminearum and the codon-optimized gene for P. pastoris was 75\% (Figure S13; Additional File 1). Due to the observation that the $\mathrm{N}$-terminal $\mathrm{His}_{10}$-tag negatively affected the production of GalOx in P. pastoris (both intra- and extracellular), the codon-optimized galox gene was cloned into the PPICZ $\alpha-C$ system with and without a C-terminal $\mathrm{His}_{6}$-tag. Both constructs were transformed into the P. pastoris strain SMD1168H to give $P$. pastoris $\mathrm{PCE}$ and $P$. pastoris $\mathrm{PxE}$, respectively (Table 1). After screening for highly-producing clones, shake-flask cultivations of $P$. pastoris FxE, $P$. pastoris $\mathrm{PxE}$, and $P$. pastoris PCE were performed in parallel at $25^{\circ} \mathrm{C}$ for $120 \mathrm{~h}$.

Table 4 Summary of productivity of galactose oxidase in different hosts

\begin{tabular}{|c|c|c|c|}
\hline strain $^{a}$ & $\begin{array}{c}\text { specific activity } \\
{\left[\mathrm{U} \cdot \mathrm{mg}^{-1}\right]}\end{array}$ & $\begin{array}{c}\text { volumetric productivity } \\
{\left[\mathrm{U} \cdot \mathrm{L}^{-1} \cdot \mathrm{h}^{-1}\right]}\end{array}$ & $\begin{array}{c}\text { specific productivity } \\
{\left[\mathrm{mg} \text { product } \cdot \mathrm{g}^{-1} \text { biomass } \cdot \mathrm{h}^{-1]}\right.}\end{array}$ \\
\hline E.coli ENI & $180 \pm 7(n=2)^{b}$ & $180 \pm 7$ & $0.15 \pm 0.1$ \\
\hline P. pastoris $\mathrm{Fxl}^{c}$ & $10(n=1)$ & 120 & n.d. ${ }^{d}$ \\
\hline P. pastoris $\mathrm{Fx} \mathrm{E}^{\mathrm{C}}$ & $260 \pm 14(n=3)$ & $610 \pm 30$ & $0.12 \pm 0.09$ \\
\hline P. pastoris PCE & $250 \pm 12(n=3)$ & $580 \pm 25$ & $0.19 \pm 0.1$ \\
\hline
\end{tabular}

\footnotetext{
${ }^{a}$ See Table 1

${ }^{b} \mathrm{n}$, number of replicates

c GalOx was not purified from crude extract

${ }^{d}$ n.d. not determined
} 


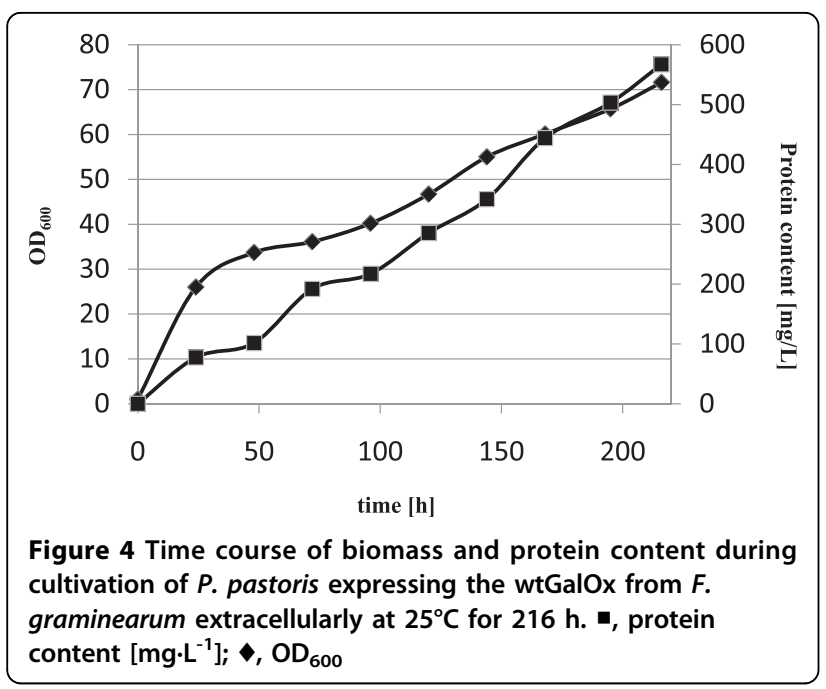

As shown in Figure 6, the amount of active GalOx obtained after $120 \mathrm{~h}$ of cultivation was very similar for all the three tested constructs. The codon-optimized gene unexpectedly did not result in an increased enzyme expression, which indicates that, although one in four nucleotides was changed from the wild-type (Additional File 1, Figure S13), codon usage does not limit translation. Regarding the $\mathrm{OD}_{600}$, the $\mathrm{DCW}$ and the protein content in the media, the three cultures showed very similar values of $\mathrm{OD}_{600}$ between $45-50$, a $\mathrm{DCW}$ between $13.5-15.0 \mathrm{mg} \cdot \mathrm{mL}^{-1}$ and a protein content of $0.29-0.32$

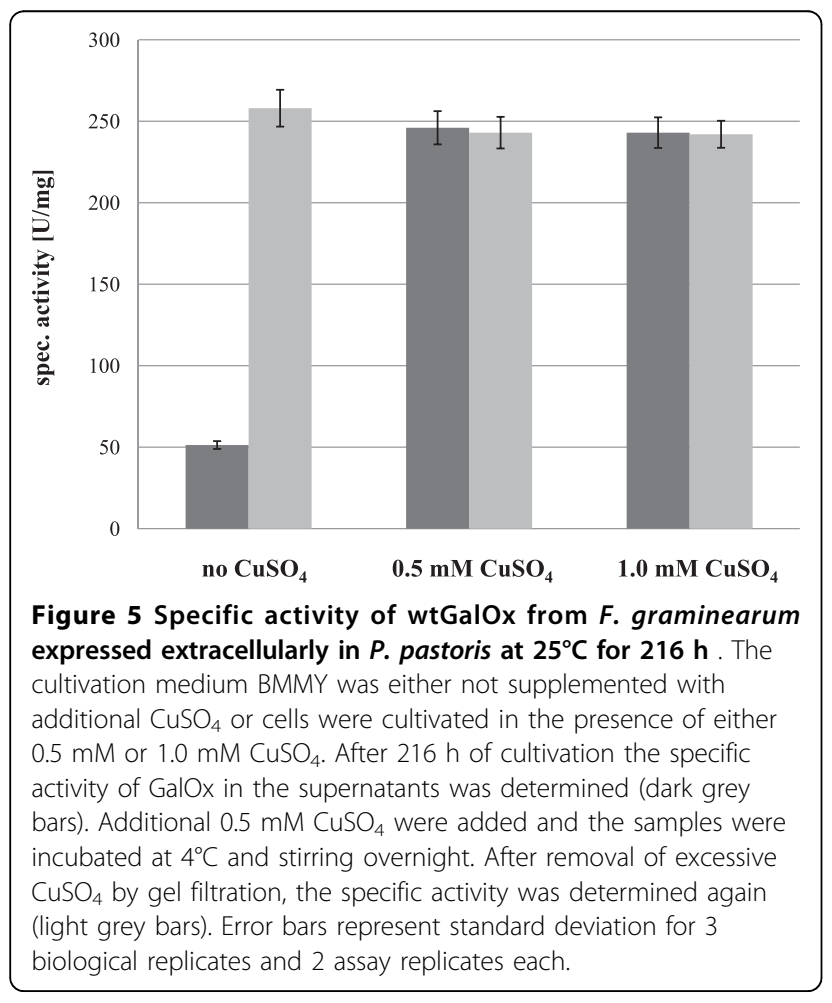

$\mathrm{mg} \cdot \mathrm{mL}^{-1}$. Incubation of the enzymes with $0.5 \mathrm{mM}$ $\mathrm{CuSO}_{4}$ at $4^{\circ} \mathrm{C}$ overnight resulted in a 4 -fold increase in activity for all 3 enzyme variants, thus indicating that the C-terminal $\mathrm{His}_{6}$-tag did not interfere with activation of GalOx by copper (II) ions. This was also supported by SDS-PAGE analysis of various samples taken during cultivation, each showing a distinct band at $65 \mathrm{kDa}$ (Figure 7A).

A subsequent IMAC purification of the $\mathrm{His}_{6}$-tagged GalOx enzyme was performed, resulting in a concentrated enzyme preparation, which could be analyzed for the correct formation of the Tyr-Cys radical by visible spectroscopy (350-800 nm). A characteristic peak at 445 $\mathrm{nm}$ confirmed the formation of the radical cofactor $[5,17]$. The purified enzyme was also analyzed by SDSPAGE and Western Blot (Figure 7B \&7C), which indicated the presence of the correctly formed radical TyrCys cofactor, the $\mathrm{His}_{6}$-tag at the C-terminus of the enzyme and a minimal amount of proteolytic degradation products. The high volumetric productivity of 580 $\mathrm{U} \cdot \mathrm{L}^{-1} \cdot \mathrm{h}^{-1}$ and possibility for simple purification by IMAC indicate that the extracellular expression of $\mathrm{GalOx}$ with a C-terminal $\mathrm{His}_{6}$-tag by $P$. pastoris is perhaps the best strategy for the large-scale production of this enzyme among the systems tested.

\section{Potential for further activation of GalOx by an inorganic oxidant}

Solutions of produced GalOx are often a mixture of the fully active $\left(\mathrm{Cu}^{2+} / \mathrm{Tyr}-\mathrm{Cys}\right)$ and the inactive $\left(\mathrm{Cu}^{2+} / \mathrm{Tyr}-\right.$ Cys) form [5,23]. Previous studies have indicated that treatment of GalOx enzyme preparations with the oxidizing agents, such as peroxidases or $\mathrm{K}_{3} \mathrm{Fe}(\mathrm{CN})_{6}$, results in the conversion of the inactive form into the fully active, radical species $[5,14,17,23,24]$. To test if the enzymes prepared in the present study could be further activated in the presence of an additional oxidizing agent, incubation of preparations with various concentrations of $\mathrm{K}_{3} \mathrm{Fe}(\mathrm{CN})_{6}$ and $\mathrm{CuSO}_{4}$ were performed. However, none of the experiments led to an additional increase in catalytic activity. Thus, the incubation of GalOx lacking the pro-peptide with $0.5 \mathrm{mM} \mathrm{CuSO}_{4}$ at $4^{\circ} \mathrm{C}$ under aerobic conditions overnight led to an efficient and apparently complete activation of the enzyme in all cases.

\section{Storage stability of extracellularly produced GalOx preparations from $P$. pastoris}

To facilitate the direct use of GalOx preparations in applications where the presence of stabilizing additives (e.g., glycerol) may complicate the downstream isolation of carbohydrate products, simple storage conditions were explored. When stored at $4^{\circ} \mathrm{C}$, the enzyme did not lose any activity for the tested period of 4 weeks. 


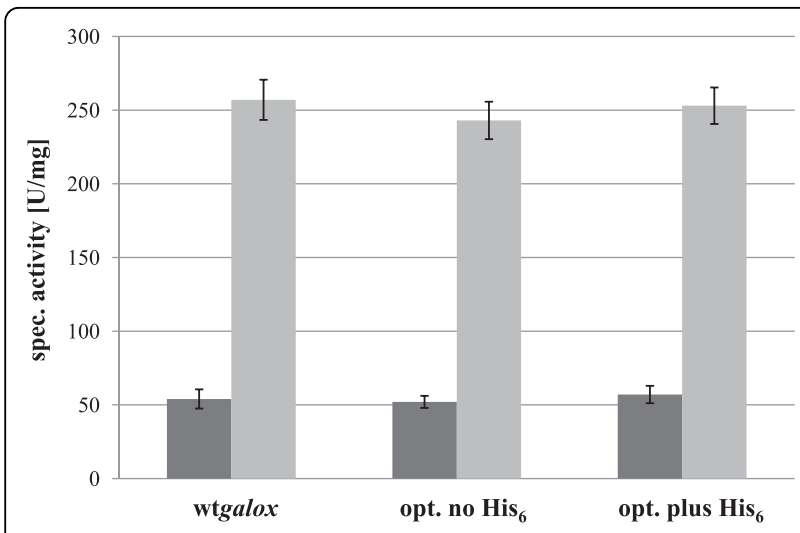

Figure 6 Specific activitiy of wtGalOx from F. graminearum or a codon-optimized variant with or without a C-terminal $\mathrm{His}_{6}$-tag expressed extracellularly in $P$. pastoris at $25^{\circ} \mathrm{C}$ for $120 \mathrm{~h}$. After $120 \mathrm{~h}$ of cultivation the specific activity of $\mathrm{GalOx}$ in the supernatants was determined (dark grey bars). Additional $0.5 \mathrm{mM} \mathrm{CuSO}_{4}$ were added and the samples were incubated at $4^{\circ} \mathrm{C}$ and stirring overnight. After removal of excessive $\mathrm{CuSO}_{4}$ by gel filtration, the specific activity was determined again (light grey bars). Error bars represent standard deviation for 2 assay replicates.

Snap-frozen $\left(\mathrm{N}_{2(l)}\right)$, lyophilized samples exhibited a $50 \%$ decrease in catalytic activity. When GalOx was otherwise snap-frozen in liquid $\mathrm{N}_{2}$, stored in aliquots at $-80^{\circ}$ $\mathrm{C}$ and thawed on ice before measurements, no loss in catalytic activity or protein content was observed.

\section{Conclusions}

In this study, codon-optimized and affinity tag variants of the galox gene from $F$. graminearum were examined for optimal heterologous intra- and extracellular production in E. coli and P. pastoris, two of the most easily accessible microbial expression hosts for general laboratory use. E. coli, in particular, is well-known as a fastgrowing host, which can be readily transformed using a range of plasmid vectors. E. coli is thus the system of choice where both high transformation efficiency and high throughput are desired, such as in protein engineering studies via directed evolution $[17,18]$. Indeed, the codon-optimized M1 variant of GalOx, bearing an $\mathrm{N}$-terminal $\mathrm{His}_{10}$ tag, is efficiently produced intracellularly in E. coli (Table 4), with both a good volumetric productivity $\left(180 \mathrm{U} \cdot \mathrm{L}^{-1} \cdot \mathrm{h}^{-1}\right)$ and high specific activity (180 U.mg ${ }^{-1}$, after IMAC purification and subsequent activation with $\mathrm{Cu}^{++}$).

The yeast $P$. pastoris, in contrast, has become one of the key eukaryotic expression hosts [27,28]. P. pastoris is transformed via chromosomal integration, with the drawback of a lower transformation efficiency than bacterial plasmid transformation, but with the advantage that stable genetic constructs are generated. The ability of $P$. pastoris to secrete proteins to the medium under

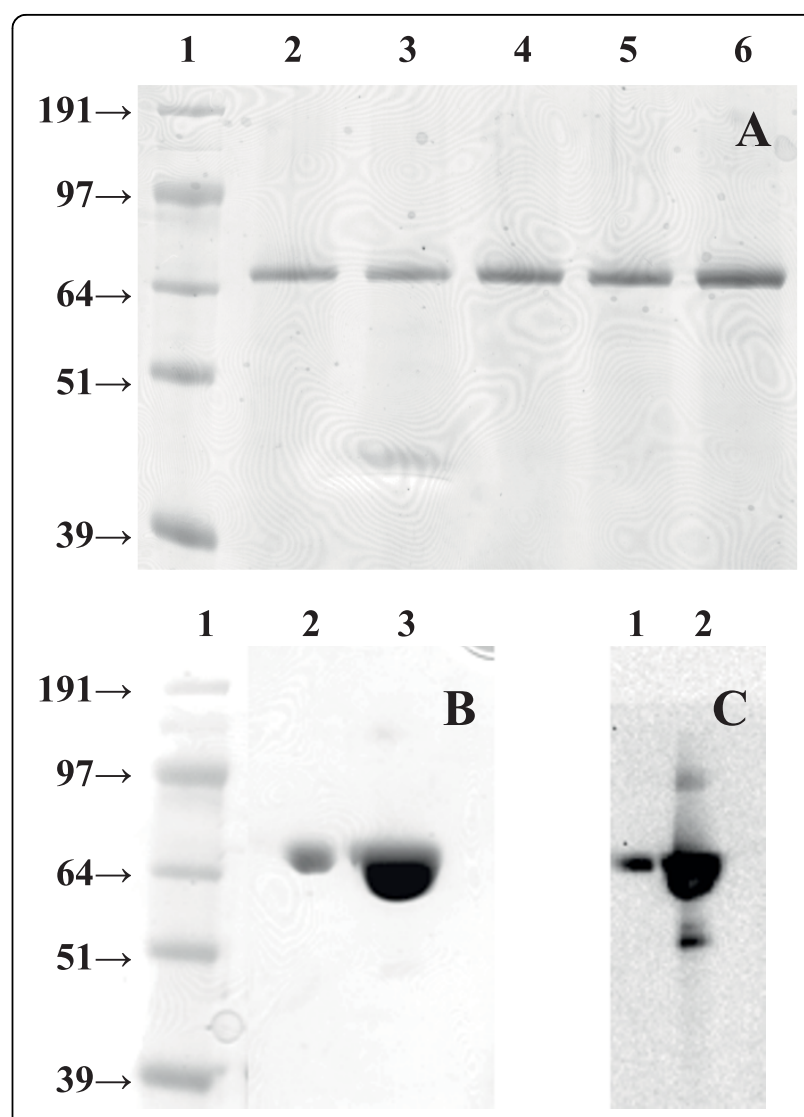

Figure 7 SDS-PAGE analysis and Western blot of the Pichiacodon-optimized GalOx gene with a C-terminal $\mathrm{His}_{6}$-tag expressed extracellularly in $P$. pastoris at $25^{\circ} \mathrm{C}$. A. SDS-PAGE analysis of aliquots of the supernatant obtained at different time points during the cultivation of $P$. pastoris expressing the codonoptimized $\mathrm{GalOx}$ gene with a C-terminal $\mathrm{His}_{6}$-tag extracellularly at $25^{\circ} \mathrm{C}$; lane 1, molecular mass standard; lane 2-6, $24 \mathrm{~h} / 48 \mathrm{~h} / 72 \mathrm{~h} / 96$ $\mathrm{h} / 120 \mathrm{~h} ; \mathrm{B}$. SDS-PAGE analysis of $10 \mu \mathrm{L}$-aliquots of the IMAC purified codon-optimized GalOx gene with a C-terminal $\mathrm{His}_{6}$-tag; lane 1, molecular mass standard; lane 2, 1:10 dilution of GalOx-His ${ }_{6}$ lane 3, pure GalOx-His $6\left(2 \mathrm{mg} \mathrm{mL}^{-1}\right)$; C. Western blot analysis of $10 \mu \mathrm{L}-$ aliquots of the IMAC purified codon-optimized GalOx gene with a C-terminal His ${ }_{\sigma}$-tag; lane 1 and 2, Western blot of 1:10 dilution of GalOx-His 6 and pure GalOx-His $\left(2 \mathrm{mg} \cdot \mathrm{mL}^{-1}\right)$.

the agency of the $\alpha$-factor secretion signal peptide confers a significant advantage to this host, by greatly simplifying downstream protein isolation. Notably, the intracellular production of GalOx in P. pastoris, was plagued by a lower volumetric productivity $\left(120 \mathrm{U} \cdot \mathrm{L}^{-1} \cdot \mathrm{h}^{-1}\right)$ than in E. coli (Table 4), a greater amount of contaminating proteins, and the lack of a facile purification due to an intolerance for $\mathrm{N}$-terminal oligo-histidine tagged constructs. In contrast, the extracellular production of the F. graminearum GalOx in this host was facile (volumetric productivity of $600 \mathrm{U} \cdot \mathrm{L}^{-1} \cdot \mathrm{h}^{-1}$, independent of yeast/fungal codon optimization, Table 4). A minimum amount of endogenous protein contaminants was 
observed, while the addition of a C-terminal $\mathrm{His}_{6}$-tag to GalOx provided a convenient strategy for removing colored medium components via IMAC. The observation that the enzyme could be directly activated to essentially similar levels by copper (II) ions added directly in the culture medium compared with post-harvest addition allows additional streamlining of $\mathrm{GalOx}$ production.

Thus, the intracellular E. coli and extracellular P. pastoris systems comprise a complementary pair for the production of GalOx, from high-throughput screening to production scale-up for applications.

\section{Additional material}

Additional file 1: Sequences of galactose oxidase genes and

primers. Complete nucleotide and derived amino acid sequences of all galactoside oxidase constructs used in this study, including oligonucleotide primers used for cloning (13 figures and 1 table).

\section{List of abbreviations used}

DCW: dry cell weight; GalOx: galactose 6-oxidase; IMAC: immobilized metal affinity chromatography; IPTG: isopropyl $\beta$-D-1-thiogalactopyranoside; ABTS: 2,2'-azinobis(3-ethylbenzthiazolinesulfonic acid)]

\section{Acknowledgements}

The Knut and Alice Wallenberg Foundation is thanked for funding via the Wallenberg Wood Science Center (http://wwsc.se/). H.B. is a Special Research Fellow (Rådsforskare) of the Swedish Research Council (Vetenskapsrådet). We thank Prof. Nicholas Turner and Dr. Julie Rannes for the optimized galox gene M1.

\section{Author details}

${ }^{1}$ Division of Glycoscience, School of Biotechnology, Royal Institute of Technology (KTH), SE-106 91 Stockholm, Sweden. ${ }^{2}$ Industrial Biotechnology, Department of Chemical and Biological Engineering, Chalmers University of Technology, SE-412 96 Gothenburg, Sweden. ${ }^{3}$ Wallenberg Wood Science Center, Royal Institute of Technology (KTH), SE-100 44 Stockholm, Sweden. ${ }^{4}$ Wallenberg Wood Science Center, Chalmers University of Technology, SE41296 Gothenburg, Sweden.

\section{Authors' contributions}

OS designed the experiments, performed the experiments and analyzed data, HB conceived the study and supervised research, LO aided experimental design and analysis, OS and HB wrote the paper. All authors read and approved the final manuscript.

\section{Competing interests}

The authors declare that they have no competing interests.

Received: 2 July 2010 Accepted: 13 September 2010

Published: 13 September 2010

\section{References}

1. Avigad G, Amaral D, Asensio C, Horecker BL: The D-galactose oxidase of Polyporus circinatus. J Biol Chem 1962, 237:2736-2743.

2. Whittaker JW: The radical chemistry of galactose oxidase. Arch Biochem Biophys 2005, 433:227-239.

3. Whittaker JW: Free radical catalysis by galactose oxidase. Chem Rev 2003 103:2347-2363.

4. Rogers MS, Tyler EM, Akyumani N, Kurtis CR, Spooner RK, Deacon SE, Tamber S, Firbank SJ, Mahmoud K, Knowles PF, et al: The stacking tryptophan of galactose oxidase: a second-coordination sphere residue that has profound effects on tyrosyl radical behavior and enzyme catalysis. Biochemistry 2007, 46:4606-4618.

5. Rogers MS, Hurtado-Guerrero R, Firbank SJ, Halcrow MA, Dooley DM, Phillips SE, Knowles PF, McPherson MJ: Cross-link formation of the cysteine 228-tyrosine 272 catalytic cofactor of galactose oxidase does not require dioxygen. Biochemistry 2008, 47:10428-10439.

6. Rogers MS, Baron AJ, McPherson MJ, Knowles PF, Dooley DM: Galactose oxidase pro-sequence cleavage and cofactor assembly are selfprocessing reactions. Journal of the American Chemical Society 2000, 122:990-991.

7. Ito N, Phillips SE, Stevens C, Ogel ZB, McPherson MJ, Keen JN, Yadav KD, Knowles PF: Novel thioether bond revealed by a $1.7 \mathrm{~A}$ crystal structure of galactose oxidase. Nature 1991, 350:87-90.

8. Szabo EE, Adanyi N, Varadi M: Application of biosensor for monitoring galactose content. Biosens Bioelectron 1996, 11:1051-1058.

9. Adanyi N, Szabo EE, Varadi M: Multi-enzyme biosensors with amperometric detection for determination of lactose in milk and dairy products. European Food Research and Technology 1999, 209:220-226.

10. Kinoshita M, Inagake K, Kawabata A, Kuroda R, Oda Y, Kakehi K: Fluorometric determination of mucin-type glycoproteins by the galactose oxidase-peroxidase method. Anal Biochem 2000, 284:87-92

11. Carter JH, Deddens JA, Pullman JL, Colligan BM, Whiteley LO, Carter HW: Validation of the galactose oxidase-Schiff's reagent sequence for early detection and prognosis in human colorectal adenocarcinoma. Clin Cancer Res 1997, 3:1479-1489.

12. Said IT, Shamsuddin AM, Sherief MA, Taleb SG, Aref WF, Kumar D: Comparison of different techniques for detection of Gal-GalNAc, an early marker of colonic neoplasia. Histol Histopathol 1999, 14:351-357.

13. Yalpani M, Hall LD: Some Chemical and Analytical Aspects of Polysaccharide Modifications .2. A High-Yielding, Specific Method for the Chemical Derivatization of Galactose-Containing Polysaccharides Oxidation with Galactose-Oxidase Followed by Reductive Amination. Journal of Polymer Science Part a-Polymer Chemistry 1982, 20:3399-3420.

14. Hartmans $S$, de Vries HT, Beijer P, Brady RL, Hofbauer M, Haandrikman AJ: Production of oxidized guar galactomannan and its applications in the paper industry. Hemicelluloses: Science and Technology 2004, 864:360-371.

15. Parikka K, Leppanen AS, Pitkanen L, Reunanen M, Willfor S, Tenkanen M: Oxidation of Polysaccharides by Galactose Oxidase. Journal of Agricultural and Food Chemistry 2010, 58:262-271.

16. Frollini E, Reed WF, Milas M, Rinaudo M: Polyelectrolytes from Polysaccharides - Selective Oxidation of Guar Gum - a Revisited Reaction. Carbohydrate Polymers 1995, 27:129-135.

17. Sun L, Petrounia IP, Yagasaki M, Bandara G, Arnold FH: Expression and stabilization of galactose oxidase in Escherichia coli by directed evolution. Protein Eng 2001, 14:699-704.

18. Escalettes F, Turner NJ: Directed evolution of galactose oxidase: generation of enantioselective secondary alcohol oxidases. Chembiochem 2008, 9:857-860

19. Deacon SE, Mahmoud K, Spooner RK, Firbank SJ, Knowles PF, Phillips SE, McPherson MJ: Enhanced fructose oxidase activity in a galactose oxidase variant. Chembiochem 2004, 5:972-979.

20. Baron AJ, Stevens C, Wilmot C, Seneviratne KD, Blakeley V, Dooley DM, Phillips SE, Knowles PF, McPherson MJ: Structure and mechanism of galactose oxidase. The free radical site. J Biol Chem 1994, 269:25095-25105.

21. Whittaker MM, Whittaker JW: $\mathrm{Cu}(\mathrm{I})$-dependent biogenesis of the galactose oxidase redox cofactor. J Biol Chem 2003, 278:22090-22101.

22. Bradford MM: A rapid and sensitive method for the quantitation of microgram quantities of protein utilizing the principle of protein-dye binding. Anal Biochem 1976, 72:248-254

23. Whittaker MM, Whittaker JW: The Active-Site of Galactose-Oxidase. Journal of Biological Chemistry 1988, 263:6074-6080.

24. Firbank SJ, Rogers M, Hurtado-Guerrero R, Dooley DM, Halcrow MA, Phillips SE, Knowles PF, McPherson MJ: Cofactor processing in galactose oxidase. Biochem Soc Trans 2003, 31:506-509.

25. Towbin H, Staehelin T, Gordon J: Electrophoretic transfer of proteins from polyacrylamide gels to nitrocellulose sheets: procedure and some applications. Proc Natl Acad Sci USA 1979, 76:4350-4354.

26. Whittaker MM, Whittaker JW: Expression of recombinant galactose oxidase by Pichia pastoris. Protein Expr Purif 2000, 20:105-111. 
27. Cregg JM, Vedvick TS, Raschke WC: Recent advances in the expression of foreign genes in Pichia pastoris. Biotechnology (N Y) 1993, 11:905-910.

28. Macauley-Patrick S, Fazenda ML, McNeil B, Harvey LM: Heterologous protein production using the Pichia pastoris expression system. Yeast 2005, 22:249-270.

29. Tschopp JF, Brust PF, Cregg JM, Stillman CA, Gingeras TR: Expression of the lacZ gene from two methanol-regulated promoters in Pichia pastoris. Nucleic Acids Res 1987, 15:3859-3876.

30. Scorer CA, Buckholz RG, Clare JJ, Romanos MA: The intracellular production and secretion of HIV-1 envelope protein in the methylotrophic yeast Pichia pastoris. Gene 1993, 136:111-119.

31. Sreekrishna K, Potenz RH, Cruze JA, McCombie WR, Parker KA, Nelles L, Mazzaferro PK, Holden KA, Harrison RG, Wood PJ, et al: High level expression of heterologous proteins in methylotrophic yeast Pichia pastoris. J Basic Microbiol 1988, 28:265-278.

32. Westerholm-Parvinen A, Selinheimo $E$, Boer $H$, Kalkkinen $N$, Mattinen $M$ Saloheimo M: Expression of the Trichoderma reesei tyrosinase 2 in Pichia pastoris: isotopic labeling and physicochemical characterization. Protein Expr Purif 2007, 55:147-158.

33. Jeong $\mathrm{H}$, Barbe $\mathrm{V}$, Lee $\mathrm{CH}$, Vallenet $\mathrm{D}$, Yu DS, Choi SH, Couloux A, Lee SW, Yoon SH, Cattolico L, et al: Genome sequences of Escherichia coli B strains REL606 and BL21(DE3). J Mol Biol 2009, 394:644-652.

34. De Schutter $K$, Lin YC, Tiels P, Van Hecke A, Glinka S, Weber-Lehmann J, Rouze $P$, de Peer $Y$, Callewaert N: Genome sequence of the recombinant protein production host Pichia pastoris. Nature Biotechnology 2009, 27:561-U104

35. Daly R, Hearn MTW: Expression of heterologous proteins in Pichia pastoris: a useful experimental tool in protein engineering and production. Journal of Molecular Recognition 2005, 18:119-138.

doi:10.1186/1475-2859-9-68

Cite this article as: Spadiut et al: A comparative summary of expression systems for the recombinant production of galactose oxidase. Microbial Cell Factories 2010 9:68.

\section{Submit your next manuscript to BioMed Central and take full advantage of:}

- Convenient online submission

- Thorough peer review

- No space constraints or color figure charges

- Immediate publication on acceptance

- Inclusion in PubMed, CAS, Scopus and Google Scholar

- Research which is freely available for redistribution

Submit your manuscript at www.biomedcentral com/submit 